\title{
Bacterial Isolation Which is Potential as Cellulosa Pedegradation in Coastal Performance in Tanjung Pinang City
}

\author{
Iwan Iskandar, Hevi Horiza * \\ Sanitation, Health Polytechnic Tanjung Pinang, Indonesia
}

hevi220987@gmail.com

\begin{abstract}
Many black water or feces and urine field observations in Tanjung Pinang City were dumped directly into the ditches, rivers and sea. This proves that the management of domestic liquid waste in the City of Tanjung pinang, especially black water, has not yet received serious attention, resulting in a decline in environmental quality. One of the stages in processing black water is decomposition. The decomposition process can be assisted by bacteria, one of which is cellulose degrading bacteria. This study aims to find bacterial isolates that have the potential to degrade cellulose in feces from coastal soils in Tanjung Pinang City. This research is a laboratory experimental research. The results of this study were obtained 16 bacterial isolates that can degrade cellulose. From these 16 isolates, 3 genera of bacteria were obtained, namely Pseudomonas, Acetobacter and Acinetobacter.
\end{abstract}

Keywords: Cellulose Degradation Bacteria, Coastal Soil

\section{Introduction}

The problem of domestic liquid waste in Indonesia is still a problem that must receive special attention from the government or the private sector. The amount of domestic wastewater generated will increase with increasing population and development in cities throughout Indonesia. This also happened in Tanjung Pinang City. Domestic liquid waste can be taken from household, industrial or other public places that contain materials that can save the environment and the lives of humans and other living things [12].

Domestic liquid waste is waste originating from various household activities. In various activities, domestic liquid waste is divided into two categories, the first is domestic liquid waste taken from washing water and the second is liquid waste originating from water closets (WC), such as feces and senior water. A septic tank is a place for human waste (feces). Good and correct management of domestic liquid waste is important in the analysis, because in this location there are still people who dispose of the gray domestic water liquid waste is still carried out in inappropriate places such as on the surface of the ground, drainage, directly into rivers, ditches, sea and any place and without simple treatment, and for the treatment of black water temporarily treated through individual septic tanks and directly into the trenches, rivers and the sea this can pollute the environment and improve health for improving environmental pollution [14].

70|EKSAKTA: Berkala IImiah Bidang MIPA 
Based on field observations of black water or feces and senior water in the City of Tanjungpinang, many were released directly into the trenches, rivers and the sea. This proves that the management of liquid waste in the City of Tanjungpinang, especially black water, has not yet received serious attention, so that the quality of the environment is increasing. Therefore, it is necessary to avoid a deterioration in environmental quality that is getting worse, so it is necessary to study how to manage it, so that it is expected that liquid waste can be managed properly.

One of the stages of domestic liquid waste management, especially black water, is in a septic tank, feces that contain lots of organic material will be degraded by decomposing microorganisms into gas and other simple organic materials. While the rest of the material that cannot be decomposed will settle into sludge [3]. Biodegradation process of organic waste generally takes longer than the speed of stool accumulation [6]. The length of time of decomposition of feces is caused by feces containing various kinds of complex organic compounds, including urea, cellulose and other organic compounds. To speed up the process of fecal biodegradation, we can add fecal decomposing bacteria. We can obtain these fecal bacteria commercially in the market or in isolation from the soil. This fecal decomposition bacteria can be in the form of cellulose-decomposing bacteria.

Research on the isolation of cellulose degrading bacteria has been carried out including research carried out by Nofu (2014) on Isolation and Characterization of Cellulose Degradation Bacteria from Yellow Cane Waste (Bagasse), the results obtained are bacterial isolates that have high cellulose degradation ability are Pseudomonas and which have Pelludomonas the lowest degradation ability is Nocardia. Ed-har (2017) conducted a study with the title Isolation and Identification of Soil Microbial Degradation Cellulose and Pectin from Rhizosfer Aquilaria malaccensis, the results obtained were microbes that showed the highest cellulose and pectin dissolution index, which was Bacillus brevis while from fungi included in the genus Helicoma.

From several studies that have been done before, no one has done isolation of cellulose degrading bacteria from coastal soils, nor has it been used in the decomposition of domestic liquid waste or feces. Therefore, researchers are interested in conducting research to determine bacterial isolates that have the potential to degrade cellulose in feces from coastal soils in Tanjung Pinang City.

\section{Experimental Section}

\subsection{Tools and Materials}

The tools used in this study were Erlemeyer, pipettes, test tubes, petri dishes, vortices, autoclaves, ose needles, bunsen, ovens, beaker glass, measuring cups, soil sample rings, scales, incubators, hoes, refrigerators, cool boxes, microscope, $\mathrm{pH}$ meter. The materials used in this research are SEA (Soil Extract Agar) Media, NA (Sodium Agar), CPAB (Citrus Pectin Agar For Bacteria), Aquades, $70 \%$ Alcohol. 


\subsection{Methods Used}

\subsubsection{Soil Sampling}

Soil sampling was carried out in a composite manner at a depth of 0-5 $\mathrm{cm}$ from the ground surface from the four cardinal points (west, east, north and south) as far as $\pm 1 \mathrm{~m}$ from the center point of the land used as the sampling location. The location of soil sampling is done randomly from each coastal area of Tanjungpinang City. The undisturbed soil samples used for weight and water content analysis were taken using a ring sampler with a height and diameter of a ring of 5 $\mathrm{cm})$ from other than the four main compass points that were very minimal.

\subsubsection{Microbial Isolation Process}

The microbial isolation process was carried out using a pouring method by making a dilution series of 10-4 to 10-7 used to isolate bacteria. SEA media are used to grow and isolate soil bacteria. Each dilution is done 3 times. The incubation process is carried out at room temperature for 3-7 days [2].

\subsubsection{Micobial Purification}

Purification aims to obtain the desired pure culture without contaminants from other microbes. Selection of purified microbial colonies based on differences in colony morphological appearance, both in terms of color, elevation, surface texture, radial lines, concentric circles or exudate drops to obtain pure isolates. Purification of bacterial isolates was carried out by transferring bacteria using the line method which was then grown on NA media [2].

\subsubsection{Dissolution Index}

The obtained bacterial isolates further tested the ability to degrade cellulose. Each isolate was grown in a special medium that is CMC based on research by Molina et al (2001) in Ed-har (2017) with some modifications. The isolates grown in selective media were incubated at room temperature for 3 days. At the end of the incubation period, isolates grown on CMC media were inundated with Congo Red $0.1 \%$. Flooding lasts for at least 15 minutes. The presence of clear zone around the isolate shows that the isolate can degrade cellulose. Then the diameter of the clear zone and colony is measured to determine the index of cellulose dissolution. The following is the formula for calculating the dissolution index [6]:

Dissolution Index $=($ Clear Zone Diameter $) /($ Colony diameter $)$

\subsubsection{Identification Microbial Colonies}

Microbial colonies that show the ability to degrade cellulose with a high dissolving index then undergo the identification process. Bacterial isolation identification process is based on Bergey's Manual of Systematic Bacteriology through the results of biochemical tests.

\section{Results and Discussion}

a. Isolation of Bacteria from the Coastal Land of Tanjung Pinang City

Soil bacterial isolation carried out at five locations in Tanjungpinang City took up 70 coastal isolates that had different morphological characteristics. Purification of isolates was carried out by the scratch method, to separate from other isolates. Purified isolates were then 
characterized and subsequently identified up to the genus level. Macroscopic observations of macroscopic 70 colonies of isolates are presented in Table 1.

Table 1. Observation Results of Morphological Isolates of Coastal Soil Bacteria in Tanjung Pinang City

\begin{tabular}{|c|c|c|c|c|c|c|}
\hline No & $\begin{array}{c}\text { Code } \\
\text { Isolat }\end{array}$ & Form & Elevation & Surface & Edge & Colour \\
\hline 1 & D4-1a & Round & Convex & Smooth & Flat & Milky white \\
\hline 2 & D4-1b & Round & Convex & Smooth & Flat & Milky white \\
\hline 3 & D4-1c & Round & Convex & Smooth & Wave & Milky white \\
\hline 4 & D4-3a & Round & Flat & Smooth & Flat & $\begin{array}{l}\text { Yellowish } \\
\text { white }\end{array}$ \\
\hline 5 & D4-3b & Round & Flat & Smooth & Flat & $\begin{array}{l}\text { Yellowish } \\
\text { white }\end{array}$ \\
\hline 6 & D4-3c & Round & Convex & Smooth & Flat & Milky white \\
\hline 7 & D1-3 & Round & Convex & Smooth & Flat & Milky white \\
\hline 8 & D3-2 & Round & Flat & Rude & Wave & $\begin{array}{l}\text { Yellowish } \\
\text { white }\end{array}$ \\
\hline 9 & KB1-1 & Round & Convex & Smooth & Flat & Milky white \\
\hline 10 & KB1-2 & Round & Convex & Smooth & Flat & Milky white \\
\hline 11 & KB1-3 & Round & Convex & Smooth & Flat & Milky white \\
\hline 12 & KB 1-4 & Round & Convex & Smooth & Flat & Milky white \\
\hline 13 & KB2-1 & Round & Convex & Smooth & Flat & Milky white \\
\hline 14 & KB2-2 & Round & Convex & Smooth & Flat & Milky white \\
\hline 15 & KB2-3 & Round & Convex & Smooth & Flat & Milky white \\
\hline 16 & KB2-4 & Round & Convex & Smooth & Flat & Milky white \\
\hline 17 & KB3-1 & Round & Convex & Smooth & Flat & Milky white \\
\hline 18 & KB3-2 & Round & Convex & Smooth & Flat & Milky white \\
\hline 19 & KB3-3 & Round & Convex & Smooth & Wave & Milky white \\
\hline 20 & KB3-4 & Round & Flat & Smooth & Flat & $\begin{array}{l}\text { Yellowish } \\
\text { white }\end{array}$ \\
\hline 21 & KB4-1 & Round & Flat & Smooth & Flat & $\begin{array}{l}\text { Yellowish } \\
\text { white }\end{array}$ \\
\hline 22 & KB4-2 & Round & Convex & Smooth & Flat & Milky white \\
\hline 23 & KB4-3 & Round & Convex & Smooth & Flat & Milky white \\
\hline 24 & KB4-4 & Round & Flat & Rude & Wave & $\begin{array}{l}\text { Yellowish } \\
\text { white }\end{array}$ \\
\hline 25 & BL1-1 & Round & Convex & Smooth & Flat & Milky white \\
\hline 26 & BL1-2 & Round & Convex & Smooth & Flat & Milky white \\
\hline 27 & BL1-3 & Round & Convex & Smooth & Flat & Milky white \\
\hline 28 & BL1-4 & Round & Convex & Smooth & Flat & Milky white \\
\hline 29 & BL2-1 & Round & Convex & Smooth & Flat & Milky white \\
\hline 30 & BL2-2 & Round & Convex & Smooth & Flat & Milky white \\
\hline 31 & BL2-3 & Round & Flat & Smooth & Flat & Milky white \\
\hline
\end{tabular}




\begin{tabular}{|c|c|c|c|c|c|c|}
\hline 32 & BL2-4 & Round & Flat & Smooth & Flat & Milky white \\
\hline 33 & BL3-1 & Round & Convex & Smooth & Flat & Milky white \\
\hline 34 & BL3-2 & Round & Convex & Smooth & Flat & Milky white \\
\hline 35 & BL3-3 & Round & Flat & Smooth & Wave & Milky white \\
\hline 36 & BL3-4 & Round & Convex & Smooth & Flat & Milky white \\
\hline 37 & BL4-1 & Round & Convex & Smooth & Flat & Milky white \\
\hline 38 & BL4-2 & Round & Convex & Smooth & Flat & Milky white \\
\hline 39 & BL4-3 & Round & Convex & Smooth & Flat & Milky white \\
\hline 40 & BL4-4 & Round & Convex & Smooth & Wave & Milky white \\
\hline 41 & TP1-1 & Round & Convex & Smooth & Flat & Milky white \\
\hline 42 & TP1-2 & Round & Convex & Smooth & Flat & Milky white \\
\hline 43 & TP1-3 & Round & Convex & Smooth & Flat & Milky white \\
\hline 44 & TP1-4 & Round & Convex & Smooth & Flat & Milky white \\
\hline 45 & TP2-1 & Round & Convex & Smooth & Flat & Milky white \\
\hline 46 & TP2-2 & Round & Convex & Smooth & Flat & Milky white \\
\hline 47 & TP2-3 & Round & Convex & Smooth & Flat & Milky white \\
\hline 48 & TP2-4 & Round & Convex & Smooth & Flat & Milky white \\
\hline 49 & TP3-1 & Round & Convex & Rude & Flat & Milky white \\
\hline 50 & TP3-2 & Round & Convex & Rude & Flat & Milky white \\
\hline 51 & TP3-3 & Round & Convex & Rude & Flat & Milky white \\
\hline 52 & TP3-4 & Round & Convex & Rude & Flat & Milky white \\
\hline 53 & TP4-1 & Round & Convex & Smooth & Flat & Milky white \\
\hline 54 & TP4-2 & Round & Convex & Smooth & Flat & Milky white \\
\hline 55 & TP4-3 & Round & Convex & Smooth & Flat & Milky white \\
\hline 56 & TP4-4 & Round & Convex & Smooth & Wave & Milky white \\
\hline 57 & TU1-1 & Round & Convex & Smooth & Flat & Milky white \\
\hline 58 & TU1-2 & Round & Convex & Smooth & Flat & $\begin{array}{l}\text { Yellowish } \\
\text { white }\end{array}$ \\
\hline 59 & TU1-3 & Round & Flat & Smooth & Flat & $\begin{array}{l}\text { Yellowish } \\
\text { white }\end{array}$ \\
\hline 60 & TU1-4 & Round & Flat & Smooth & Flat & Milky white \\
\hline 61 & TU2-1 & Round & Convex & Smooth & Flat & Milky white \\
\hline 62 & TU2-2 & Round & Convex & Smooth & Flat & $\begin{array}{l}\text { Yellowish } \\
\text { white }\end{array}$ \\
\hline 63 & TU2-3 & Round & Flat & Smooth & Flat & Milky white \\
\hline 64 & TU2-4 & Round & Flat & Smooth & Flat & Milky white \\
\hline 65 & TU3-1 & Round & Flat & Smooth & Wave & Milky white \\
\hline 66 & TU3-2 & Round & Convex & Smooth & Flat & Milky white \\
\hline 67 & TU3-4 & Round & Convex & Smooth & Flat & Milky white \\
\hline 68 & TU4-1 & Round & Flat & Smooth & Flat & $\begin{array}{l}\text { Yellowish } \\
\text { white }\end{array}$ \\
\hline 69 & TU4-3 & Round & Flat & Smooth & Flat & Milky white \\
\hline 70 & TU4-4 & Round & Flat & Smooth & Wave & Milky white \\
\hline
\end{tabular}


Observation of the growth of cellulotic bacteria from the coastal land of Tanjungpinang City was carried out after the 7th day of bacterial isolation from soil samples grown on the SEA medium. From the isolation results, bacterial isolates were then transferred into NA media for culture and purification stock. Of the 70 isolates obtained, the least isolates were found in the Dompak Coastal area where only 8 isolates were obtained from 4 locations of soil sampling locations, namely D4-1a isolates; D4-1b; D4-1c; D4-3a; D4-3b; D4-3c; D1-3; D3-2. Bacterial isolates that do not grow are soil samples taken near the shoreline of the sea. In general, bacterial isolates obtained macroscopically are round with a smooth and milky white surface.
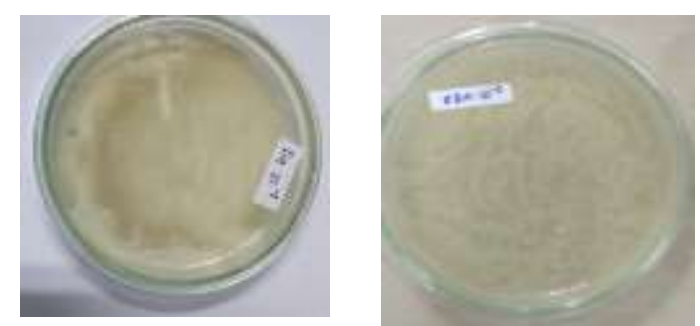

Figure 1 Bacteria that Grow on SEA and NA Medium

b. Bacterial Isolation Cellulose degradation

All bacteria that grow on NA agar media are all planted into CMC agar media and grown for 3 to 5 days. After incubation for 3 days, a potential test was done to degrade cellulose in CMC media so that the Congo Red dye was dripped so that a clear zone was seen around the cellulotic bacterial colony. In the screening test results, it turns out that not all isolates that are suspected to be cellulotic bacteria can degrade cellulose. Of the 70 isolates found, only 16 isolates were proven to be able to degrade cellulose. Table 5.2 shows isolates that positively degrade cellulose with their cellulotic index. Clear zone formed as a result of the action of cellulose enzymes secreted by bacterial isolates. Although this method is a testing method that is quite sensitive for the isolation and selection of cellulose degrading bacteria. However, the diameter of this clear zone is not an indicator of the quantity of enzyme activity released or secreted by bacterial isolates [2].

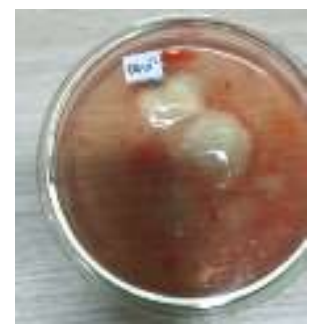

Figure 2 Clear Zone Cellulotic Activity Test Results 
Table 2. Results of Screening of Cellulotic Bacteria Isolates and Cellulotic Index

\begin{tabular}{ccc}
\hline No & Code & Disullution Index \\
\hline 1 & KB2-3 & 2,3333 \\
2 & KB3-1 & 1,5000 \\
3 & KB4-4 & 0,6667 \\
4 & TP1-3 & 0,6000 \\
5 & TP2-3 & 1,5000 \\
6 & BL3-2 & 1,6667 \\
7 & BL3-4 & 1,0000 \\
8 & TU2-3 & 1,5000 \\
9 & D4-1a & 1,1429 \\
10 & D4-1b & 1,2222 \\
11 & D4-1c & 0,4286 \\
12 & D4-3a & 1,0000 \\
13 & D4-3b & 2,0000 \\
14 & D4-3c & 1,8571 \\
15 & D1-3 & 1,0000 \\
16 & D3-2 & 1,0000 \\
\hline
\end{tabular}

c. Characterization of bacterial isolates

The cellulose degrading bacteria which were isolated from the coastal land of Tanjungpinang City amounted to 16 isolates which were then identified using bacterial physiological tests to determine the genus of the bacteria found. The physiological characteristics of each bacterium can be seen in Table 3. The general characteristics shown are gram-negative, rod-shaped bacteria, which cannot grow at 50oC and grow aerobically (Table 3 ).

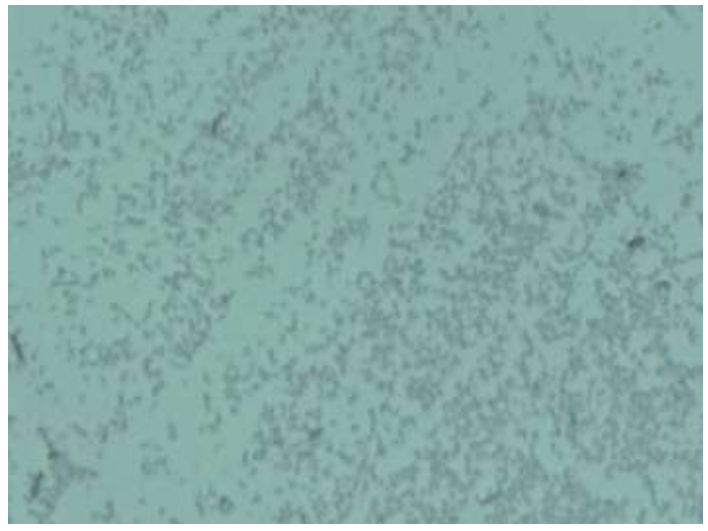

Figure 3 Results of Gram Staining of Cellulose Degradation Bacteri 
Table 3 Physiological Characteristics of Cellulotic Bacteria Isolates

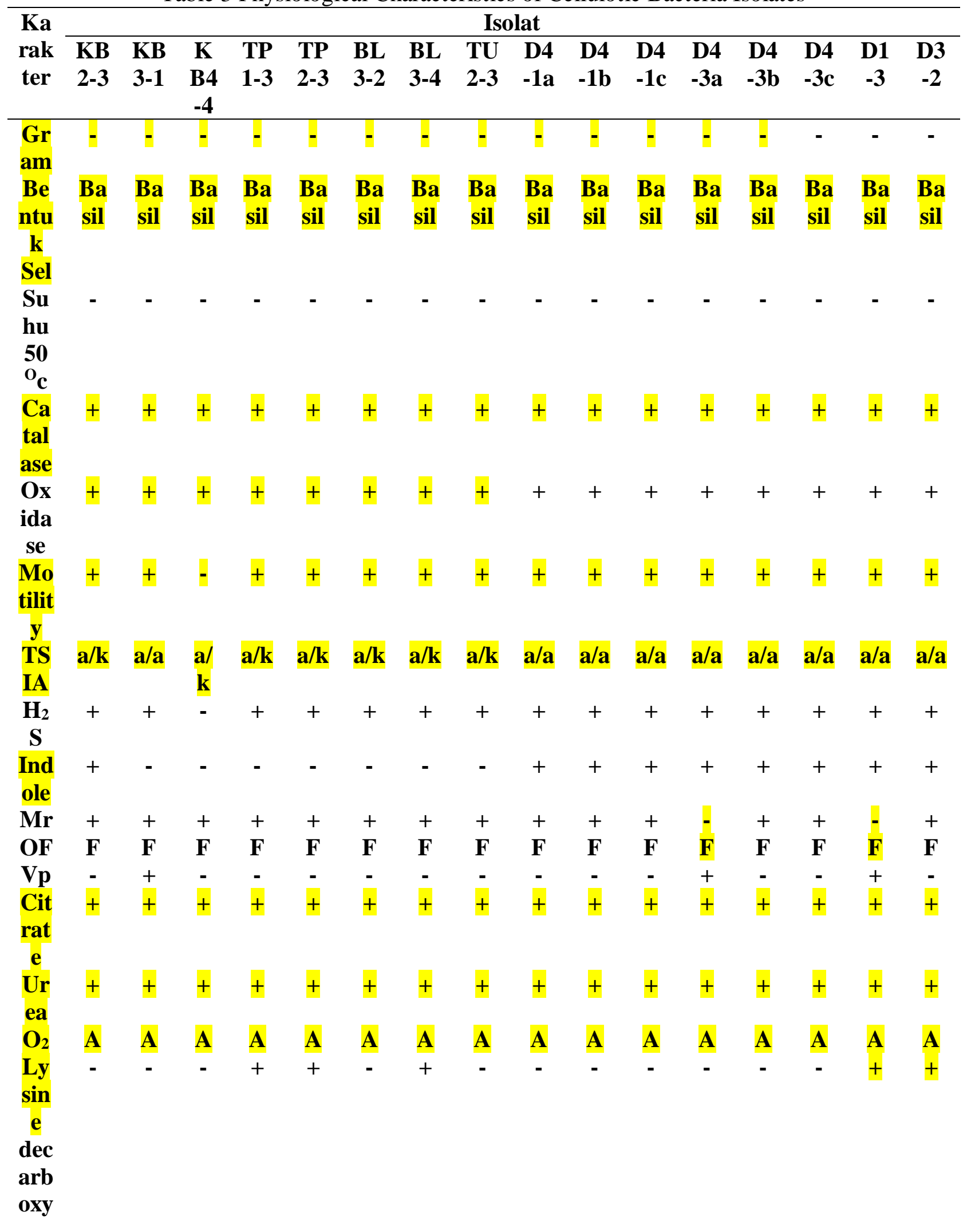


las

e

Or

nit

hin

e

dec

arb

oxy

las

e

Gel $+\quad+\quad+\quad+\quad-\quad+\quad+\quad+\quad+\quad+\quad+\quad+\quad+\quad+\quad+\quad+$ ati

n

hid

roli

sis

Nit

rat

e

Re

du

cti

on $\underset{\mathrm{uk}}{\mathrm{Gl}}+\mathrm{t}+\mathrm{t}+\mathrm{t}+\mathrm{t}+\mathrm{t}+\mathrm{t}+\mathrm{t}+$

osa

$\mathrm{Ga} \quad-\quad-\quad-\quad-\quad+\quad+\quad-\quad+\quad+\quad+\quad+\quad+\quad+\quad+\quad+\quad+$

$\mathbf{S}$

La

kto

sa

$\mathrm{Su} \quad-\quad+\quad-\quad+\quad+\quad+\quad+\quad-$

kro

sa

$\mathrm{Ma}+\quad+\quad+\quad+\quad+\quad+\quad+\quad+$

Itos

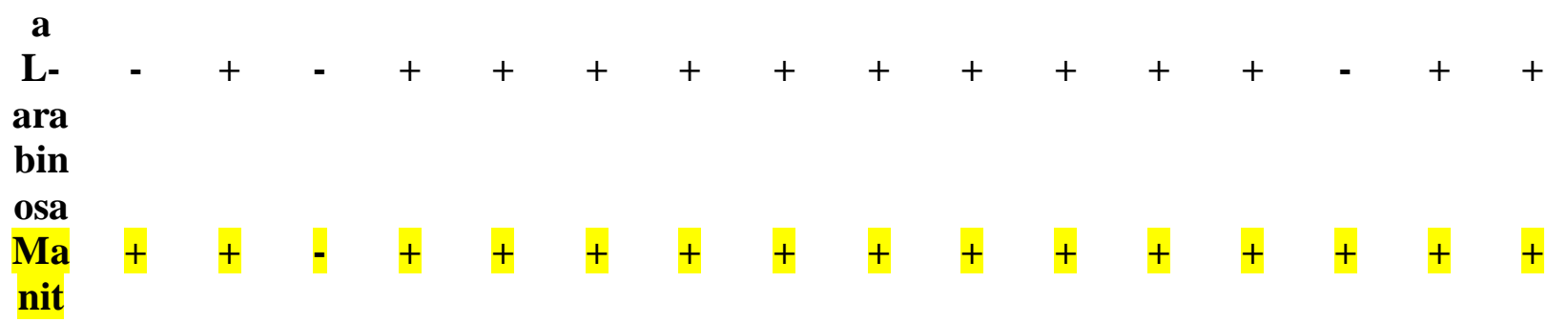
78IEKSAKTA: Berkala IImiah Bidang MIPA 


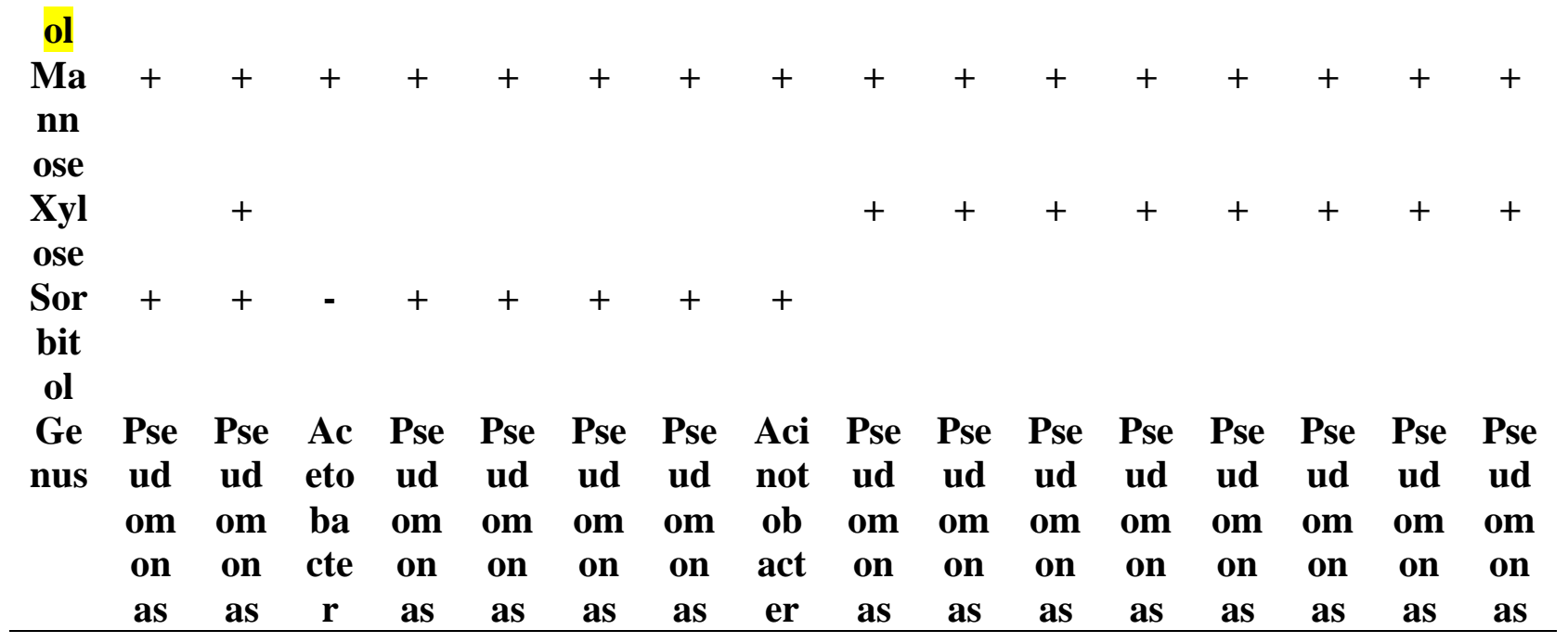

d. Observed Environmental Parameters

Table 4 Results of Field Observations on Soil Samples

\begin{tabular}{|c|c|c|c|c|c|c|c|}
\hline No & Wilayah & $\begin{array}{c}\text { Sample } \\
\text { Code }\end{array}$ & $\begin{array}{l}\mathrm{pH} \\
\text { Soil }\end{array}$ & $\begin{array}{c}\text { Enviromental } \\
\text { Themperature } \\
\left({ }^{\circ} \mathrm{C}\right)\end{array}$ & $\begin{array}{c}\text { Soil } \\
\text { Themperature } \\
\left({ }^{\circ} \mathrm{C}\right)\end{array}$ & $\begin{array}{l}\text { Humidity } \\
\text { (RH) }\end{array}$ & $\begin{array}{c}\text { Water } \\
\text { Content } \\
(\%)\end{array}$ \\
\hline \multirow[t]{4}{*}{1} & Dompak & D1 & 7 & 29 & 26 & 80 & 25,6833 \\
\hline & & D2 & 7 & 29 & 26 & 30 & 21,4220 \\
\hline & & D3 & 7 & 29 & 26 & 100 & 34,0264 \\
\hline & & D4 & 8 & 29 & 27 & 10 & 9.0050 \\
\hline \multirow[t]{4}{*}{2} & Tanjung & TU 1 & 7 & 31 & 26 & 20 & 16,4828 \\
\hline & & TU 2 & 8 & 31 & 26 & 20 & 17,9719 \\
\hline & & TU 3 & 8 & 31 & 26 & 50 & 19,7199 \\
\hline & & TU 4 & 7 & 31 & 26 & 100 & 28,4602 \\
\hline \multirow[t]{4}{*}{3} & Tugu & TP 1 & 8 & 30 & 27 & 20 & 19,7311 \\
\hline & & TP 2 & 8 & 30 & 27 & 20 & 18,2194 \\
\hline & & TP 3 & 8 & 30 & 27 & 20 & 16,8263 \\
\hline & & TP 4 & 7 & 30 & 27 & 10 & 11,3861 \\
\hline \multirow[t]{4}{*}{4} & Kampung & KB 1 & 7 & 30 & 27 & 10 & 16,8047 \\
\hline & & KB 2 & 6 & 30 & 26 & 20 & 25,1274 \\
\hline & & KB 3 & 8 & 30 & 27 & 50 & 20,7174 \\
\hline & & KB 4 & 8 & 30 & 27 & 30 & 22,6605 \\
\hline \multirow[t]{2}{*}{5} & Kampung & BL 1 & 8 & 29 & 26 & 50 & 50,1113 \\
\hline & & BL 2 & 8 & 29 & 26 & 100 & 38,5433 \\
\hline
\end{tabular}




\begin{tabular}{llllll} 
BL 3 & 7 & 29 & 26 & 80 & 43,6909 \\
BL 4 & 7 & 29 & 26 & 90 & 39,5838 \\
\hline
\end{tabular}

\section{e. Statistic Analysis}

The results of statistical analysis show that there is an influence of soil $\mathrm{pH}$ on cellulotic $\mathrm{P}$ value $(<0.05)$, but the effect of $\mathrm{pH}$ on cellulotics goes in the opposite direction to the Coccelation Coefficient $(-0,772)$. If the soil $\mathrm{pH}$ drops, the cellulotic index will rise and vice versa if the soil $\mathrm{pH}$ rises, the cellulotic index will decrease. The results of statistical analysis show that there is an effect of soil temperature on cellulotic $\mathrm{P}$ value $(<0.05)$, but the effect of soil temperature on cellulotics goes in the opposite direction to the Coccelation Coefficient $(-0,691)$. If the soil temperature drops, the cellulotic index will rise and vice versa if the soil temperature rises, the cellulotic index will decrease. The results of statistical analysis show that there is an influence of humidity on cellulotic $\mathrm{P}$ value $(<0.05)$, the effect of humidity on cellulotics goes in the same direction and the effect is very strong Coccelation Coefficient (0.955). If the humidity decreases, the cellulotic index will also decrease and vice versa if the humidity rises, the cellulotic index will also rise. For water content and ambient temperature showed no effect on the index of cellulotic activity.

Isolation of cellulose degrading bacteria from 5 soil sampling locations obtained 16 isolates (table 5.2). each isolate was tested on a series of media to see the biochemical activity of the bacteria. The biochemical activity of each type of bacteria is different because each bacterium has a different enzymatic activity [15]. Based on the identification results obtained by 3 genera namely Pseudomonas, Acetobacter and Acinobacter. Pseudomonas genus (isolates KB2-3, KB3-1, TP1-3, TP2-3, BL3-2, BL3-4, D4-1a, D4-1b, D4-1c, D4-3a, D4-3b, D4- 3c, D13 and D3-2) have a rod and gram negative form, the results of the biochemical test are positive catalase, positive or negative motility, positive ornithin, positive citrate hydrolysis positive gelatin and do not contain $\mathrm{H}_{2} \mathrm{~S}$ [4]. The genus Acetobacter (KB4-4 isolate) has stem-shaped cells and belongs to the group of gram-negative bacteria. This bacterium is non motile and produces the enzyme catalase. This isolate is not able to do gelatin hydrolysis but is able to utilize several sugar compounds such as glucose, lactose, maltose and sucrose. Some members of the genus Acetobacter are motile and non-motile. Acetobacter genus does not form endospores, aerobic life is obligate, does not do alcohol fermentation, oval-shaped to short stems. This bacterial metabolism produces the enzyme catalase [4][15]. The genus Acinetobacter (isolate TU2-3) has the form of cocobacil and is a class of gram-negative bacteria. This bacterium is aerobic and has a catalase enzyme. Acinetobacter can utilize glucose, mannitol, maltose and sucrose. These genus bacteria utilize sugar by oxidation [15]. Cells do not form spores and are not motile. Acinetobacter genus can grow in a temperature range of $20^{\circ}-30^{\circ} \mathrm{C}$, but most can grow optimally at $33^{\circ}-35^{\circ} \mathrm{C}[1]$.

Based on data from the measurement of environmental physics parameters listed in table 4, it shows that the five research sites have some of the same environmental conditions. Where the average air temperature at the five study sites was $29.8^{\circ} \mathrm{C}$. This happens because the sampling is done during the day. The average temperature is the optimum temperature for bacterial breeding 
[6]. Table 4 shows that the average soil temperature from the study site is the optimum temperature for bacterial growth. Where the optimum temperature for bacterial growth ranges from $27-36^{\circ} \mathrm{C}$ [5]. This temperature is a good temperature for the decomposition process.

Based on the results of the correlation test conducted, it can be seen that the activity of cellulotic bacteria is influenced by soil $\mathrm{pH}$. Where the lower the $\mathrm{pH}$ of the soil to eat the higher the index of cellulotic activity. For example isolate KB2-3 the soil $\mathrm{pH}$ is 6 index cellulotic activity 2.33333 while isolate $\mathrm{D} 4-1 \mathrm{c}$ the soil $\mathrm{pH} 8$ index cellulotic activity is 0.4286 . Soil $\mathrm{pH}$ values for the five study sites were 7-8 (Table 4). However, this $\mathrm{pH}$ value is still the optimum $\mathrm{pH}$ for the growth of cellulose degrading bacteria. The most suitable $\mathrm{pH}$ range for bacterial growth is 6-8. Cellulose degrading bacteria can survive because they can form spores as protection from extreme environmental conditions such as in coastal areas [8].

Correlation test between soil temperature and cellulotic activity shows that if the soil temperature drops, the cellulotic index will rise and vice versa if the soil temperature rises the cellulotic index will decrease. This can be seen in the KB2-3 isolate, the soil temperature is $26^{\circ} \mathrm{C}$, the cellulotic activity index is 2.33333 while the $\mathrm{D} 4-1 \mathrm{a}$ isolate is $27^{\circ} \mathrm{C}$, the cellulotic activity index is 0.4286 . This is also supported by biochemical test data that the isolated bacteria cannot grow at $50^{\circ} \mathrm{C}$.

\section{Conclusion}

From the research results, it can be concluded that obtained isolates of bacteria from coastal samples of Tanjungpinang City as many as 70 isolates, isolates of bacteria that have the ability to degrade cellulose there are 16 isolates and from 16 isolates that are able to degrade cellulose obtained 3 genus of bacteria namely Pseudomonas, Acetobacter and Acinetobacter .

\section{Acknowledgement}

I gratefully thank to the principal of Health Polytechnic Tanjungpinang, Mr. Novian Aldo, SST., MM for allowing me to conduct the research there. Also thank For tim research and the special one for my patner Mrs Hevi Horiza for allowing me to conduct my research. I could never have finished this without you.

\section{References}

[1] Gillezeau C, van Gerwen M, Shaffer RM, Rana I, Zhang L, Sheppard L, et al. The evidence of human exposure to glyphosate: a review. Environmental health : a global access science source. 2019;18(1):2.

[2] Ed-har, Adiz Adryan, Rahayu Widyastuti dan Gunawan Djajakirana. Isolasi dan Identifikasi Mikroba Tanah Pendegradasi Selulosa dan Pektin dari Rhizosfer Aquilaria malaccensis. Buletin Tanah dan Lahan, Vol.1, No.1 (2017)

[3] Firdus dan Z.A. Muchlisin, "Degradation Rate Of Sludge and Water Quality of Tangki septik (Water Closed) by Using Starbio and Freshwater Catfish as Biodegradator". Jurnal Natural, Vol.10, No. 1 (2010). 
[4] Pesewu GA, Bentum D, Olu-Taiwo MA, Glover KK, Yirenya-Tawiah DR. Bacteriological quality of the wastewater used for irrigation at the vegetable farms in Korle-bu Teaching Hospital, Accra Metropolis, Ghana. Tropical doctor. 2017;47(1):15-9.

[5] Donnellan Barraclough A, Zweifel R, Cusens J, Leuzinger S. Disentangling the net: concomitant xylem and over-bark size measurements reveal the phloem-generated turgor signal behind daytime stem swelling in the mangrove Avicennia marina. Functional plant biology : FPB. 2019.

[6] Ningsih, Rizqie Lestya, Siti Khotimah, Irwan Lovadi. Bakteri Pendegradasi Selulosa dari Searah Daun Avicennia alba Blume di Kawasan Hutan Mangrove Peniti Kabupaten Pontianak. Jurnal Protobiont, Vol.3, No.1, (2014)

[7] Nofu, Krispina, Siti Khotimah, Irwan Lovadi. Isolasi dan Karakterisasi Bakteri Pendegradasi Selulosa pada Ampas Tebu Kuning (Bagasse). Jurnal Protobiont, Vol.3, No.1, (2014)

[8] Solagaistua L, de Guzman I, Barrado M, Mijangos L, Etxebarria N, Garcia-Baquero G, et al. Testing wastewater treatment plant effluent effects on microbial and detritivore performance: A combined field and laboratory experiment. Aquatic toxicology. 2018;203:159-71.

[9] Feng Y, Zhao X, Guo Y, Yang G, Xi J, Ren G. Changes in the material characteristics of maize straw during the pretreatment process of methanation. Journal of biomedicine \& biotechnology. 2012;2012:325426.

[10] Chen J, Yoshinaga M, Rosen BP. The antibiotic action of methylarsenite is an emergent property of microbial communities. Molecular microbiology. 2019;111(2):487-94.

[11] Lamers LP, Govers LL, Janssen IC, Geurts JJ, Van der Welle ME, Van Katwijk MM, et al. Sulfide as a soil phytotoxin-a review. Frontiers in plant science. 2013;4:268.

[12] Staley C, Ferrieri AP, Tfaily MM, Cui Y, Chu RK, Wang P, et al. Diurnal cycling of rhizosphere bacterial communities is associated with shifts in carbon metabolism. Microbiome. 2017;5(1):65.

[13] Li R, Dorfler U, Munch JC, Schroll R. Enhanced degradation of isoproturon in an agricultural soil by a Sphingomonas sp. strain and a microbial consortium. Chemosphere. 2017; 168:1169-76.

[14] Venkataraman A, Sieber JR, Schmidt AW, Waldron C, Theis KR, Schmidt TM. Variable responses of human microbiomes to dietary supplementation with resistant starch. Microbiome. 2016;4(1):33.

[15] Schroder P, Helmreich B, Skrbic B, Carballa M, Papa M, Pastore C, et al. Status of hormones and painkillers in wastewater effluents across several European statesconsiderations for the EU watch list concerning estradiols and diclofenac. Environmental science and pollution research international. 2016;23(13):12835-66.

[16] Wang Q, Ji F, Wang J, Jiang B, Li L, An L, et al. Characterization of a salt-activated protease with temperature-dependent secretion in Stenotrophomonas maltophilia FF11 isolated from frozen Antarctic krill. Journal of industrial microbiology \& biotechnology. 2016;43(6):829-40.

[17] Weyens N, Thijs S, Popek R, Witters N, Przybysz A, Espenshade J, et al. The Role of Plant-Microbe Interactions and Their Exploitation for Phytoremediation of Air Pollutants. International journal of molecular sciences. 2015;16(10):25576-604. 
[18] Obermeier M, Schroder CA, Helmreich B, Schroder P. The enzymatic and antioxidative stress response of Lemna minor to copper and a chloroacetamide herbicide. Environmental science and pollution research international. 2015;22(23):18495-507.

[19] Chen M, Xu P, Zeng G, Yang C, Huang D, Zhang J. Bioremediation of soils contaminated with polycyclic aromatic hydrocarbons, petroleum, pesticides, chlorophenols and heavy metals by composting: Applications, microbes and future research needs. Biotechnology advances. 2015;33(6 Pt 1):745-55.

[20] Zhang SY, Zhao FJ, Sun GX, Su JQ, Yang XR, Li H, et al. Diversity and abundance of arsenic biotransformation genes in paddy soils from southern China. Environmental science \& technology. 2015;49(7):4138-46.

[21] Lee CL. The advantages of deep ocean water for the development of functional fermentation food. Applied microbiology and biotechnology. 2015;99(6):2523-31. 